\title{
ŠEZDESET PET GODINA \\ KNJIŽNICE SESVETE
}

\author{
SIXTY-FIVE YEARS \\ OF THE SESVETE LIBRARY
}

\begin{abstract}
Iva Klak Mršić
Knjižnice Grada Zagreba

iva.klak.mrsic@kgz.hr

Ivan Babić

Knjižnice Grada Zagreba

ivan.babic@kgz.hr

Keti Krpan

Knjižnice Grada Zagreba

keti.krpan@kgz.hr

Jelena Pisačić

Knjižnice Grada Zagreba

jelena.pisacic@kgz.hr
\end{abstract}

UDK / UDC: 027.022“1956/2021“(497.521.2

Sesvete)(091)

Pregledni rad / Review paper

Primljeno / Received: 28. 8. 2021.

Prihvaćeno / Accepted: 10. 10. 2021.

\section{Sažetak}

Cilj. Cilj je rada ukratko prikazati povijest mreže Knjižnice Sesvete koju danas čine Knjižnica Sesvete (koja djeluje kao područna knjižnica) s tri ogranka: Knjižnicom Dubec, Knjižnicom Selčina i Knjižnicom Jelkovec. Od 1986. godine Knjižnica Sesvete s ograncima čini dio mreže Knjižnica grada Zagreba. 
Pristup/metodologija. Kronološki prikaz daje se od osnutka knjižnice 1956. godine kao prve narodne knjižnice na području tadašnje općine, a današnje gradske četvrti Sesvete. Podaci o Knjižnici prikupljeni su u arhivi Knjižnice Sesvete, u stručnim radovima objavljenima o programima Knjižnice te na mrežnim stranicama. Uz kronološki prikaz rad prikazuje knjižnične programe i usluge, kao i druge pokazatelje rada i djelovanja Knjižnice Sesvete u lokalnoj zajednici.

Rezultati. Koristeći se dostupnim podacima, u radu se nastojalo dati povijesni pregled razvoja Knjižnice Sesvete i ogranaka od njihova osnutka do današnjih dana. U skladu s društvenim i demografskim promjenama u lokalnoj sredini, mijenjale su se knjižnične usluge i programi Knjižnice.

Originalnost/vrijednost. Rad je prvi kronološki prikaz povijesti Knjižnice Sesvete od njezinog osnutka 1956. godine do danas te bi mogao biti polazište za iscrpnije istraživanje i cjelovitiji opis.

Ključne riječi: Knjižnica Dubec, Knjižnica Jelkovec, Knjižnica Selčina, Knjižnica Sesvete, narodne knjižnice - povijest

\section{Abstract}

Aim and purpose. The aim of this paper is to briefly present the history of the Sesvete Library network, which today consists of the Sesvete Library (which acts as a district library) with three branches: the Dubec Library, the Selčina Library, and the Jelkovec Library. Since 1986, the Sesvete Library with its branches has been part of the Zagreb City Library network.

Approach/Methodology. The paper gives a chronological overview of the Sesvete Library since the founding in 1956 as the first public library in the area of the then municipality, and today's city district of Sesvete. The research data on the Library were collected in the archives of the Sesvete Library, in professional papers dealing with the Library's programs, and on the Library website. In addition to the chronological outline, the paper presents library programs and services, as well as other indicators of the work and activities of the Sesvete Library in the local community.

Results. Using the available data, the paper seeks to provide a historical overview of the development of the Sesvete Library and its branches from their founding to the present day. In line with social and demographic changes that have occurred in the local environment, the Library services and programs have changed, too.

Originality/value. The paper presents the first chronological overview of the history of the Sesvete Library from its founding in 1956 until today and could be a starting point for a more comprehensive research and a more exhaustive description.

Keywords: Dubec Library, Jelkovec Library, Selčina Library, Sesvete Library, public libraries - history 


\section{Uvod}

Knjižnica Sesvete osnovana je 1956. godine te se u 2021. godini obilježava 65. godišnjica osnutka knjižnice u Sesvetama. Od 1956. do 1972. godine Narodna knjižnica Sesvete bila je samostalna knjižnica. U sastavu Narodnog sveučilišta Sesvete knjižnica je djelovala od 1972. do 1985. godine, a od 1986. godine u sastavu je Knjižnica grada Zagreba. Danas Knjižnica Sesvete ${ }^{1}$ djeluje kao područna knjižnica u mreži Knjižnica grada Zagreba, sa svojim ograncima Knjižnicom Dubec, ${ }^{2}$ Knjižnicom Selčina ${ }^{3}$ i Knjižnicom Jelkovec. ${ }^{4}$

Geografski i pozicijski Gradska četvrt Sesvete nalazi se izvan samostalnog naselja Zagreb i čine je gradsko naselje Sesvete te 36 samostalnih pretežno ruralnih naselja. ${ }^{5}$ Danas su Sesvete najistočnija i najveća gradska četvrt, površine od 165255 $\mathrm{km}^{2}$. Područje današnje gradske četvrti podijeljeno je nakon Drugog svjetskog rata između Kotara Zagreb i Kotara Sv. Ivan Zelina. Općina Sesvete, koja je obuhvaćala cijelo područje današnje gradske četvrti i područje Dupca, osnovana je 1955. kao jedna od općina proširenog Kotara Zagreb. Prva faza transformacije Sesveta iz agrarnog u urbano naselje bila je pod utjecajem procesa industrijalizacije i suburbanizacije koji su započeli nakon Drugog svjetskog rata. Tijekom 1960-ih godina otvaraju se i proširuju najveći industrijski pogoni u Sesvetama, a gradi se i prva industrijska zona južno od željezničke pruge. Takav razvoj industrije stvorio je potrebu za radnom snagom, što je utjecalo na strukturu zaposlenog stanovništva u kojoj je do 1961. glavna gospodarska grana bila poljoprivreda. ${ }^{6}$ Sesvete 1962. godine postaju općinom užeg gradskog područja, ali 1967. godine, kada se općine užeg gradskog područja spajaju u jedinstveni Grad Zagreb, ostaju samostalna općina. Broj doseljenog stanovništva u 1960-im godinama u Sesvetama je značajno premašio broj autohtonog stanovništva, a intenzivan porast naselja Sesvete uočava se nakon popisa stanovništva 1961. godine i traje sve do danas. Od 1975. sesvetska je općina u sastavu Zajednice općina Zagreb, a 1982. postaje jednom od 14 općina Gradske zajednice općina Zagreb. Tijekom 1980-ih godina zbog mnogobrojnih kriza industrijski pogoni gube svoju važnost, a tijekom 1990-ih godina većina ih se zatvara. U 1970-im godinama uvodi se javni prijevoz koji omogućava

\footnotetext{
1 Knjižnice grada Zagreba. Knjižnica Sesvete. [citirano: 2021-04-08]. Dostupno na: http:// www.kgz.hr/hr/knjiznice/knjiznica-sesvete/85.

2 Knjižnice grada Zagreba. Knjižnica Dubec. [citirano: 2021-04-08]. Dostupno na: http://www. kgz.hr/hr/knjiznice/knjiznica-dubec/69.

3 Knjižnice grada Zagreba. Knjižnica Selčina. [citirano: 2021-04-08]. Dostupno na: http://www. $\mathrm{kgz.hr} / \mathrm{hr} / \mathrm{knjiznice/knjiznica-selcina/84.}$

4 Knjižnice grada Zagreba. Knjižnica Jelkovec. [citirano: 2021-04-08]. Dostupno na: http:// www.kgz.hr/hr/knjiznice/knjiznica-jelkovec/7116.

5 Grad Zagreb: Gradska četvrt Sesvete. [citirano: 2021-10-05]. Dostupno na: https://aktivnosti. zagreb.hr/gradske-cetvrti-19/sesvete/163.

6 Usp. Malić, A. Transformacija Sesveta pod utjecajem Zagreba. // Hrvatski geografski glasnik 31, 1(1969), str. 143-153. [citirano: 2021-05-10]. Dostupno na: https:// hrcak.srce.hr/56058.
} 
stanovništvu šireg sesvetskog područja dnevne migracije, što je dovelo do toga da Sesvete od industrijskog središta postaju stambeno središte. ${ }^{7}$ Općina Sesvete, kao i druge zagrebačke općine, prestala je postojati 31. prosinca 1990. godine. Od 1991. do 2001. godine broj stanovnika Gradske četvrti Sesvete povećao se za 11338 stanovnika, što je najveći porast broja stanovnika između dvaju popisa stanovništva u Republici Hrvatskoj. Druga faza doseljavanja na područje gradske četvrti Sesvete započela je doseljavanjem stanovništva iz ratom pogođenih područja, uglavnom iz Bosne i Hercegovine, ali i iz Hrvatske, od 1990. godine. ${ }^{8}$ Prema Popisu stanovništva iz 2001. godine, 21806 (36,8 \%) stanovnika Gradske četvrti Sesvete živi u istom naselju od rođenja, a $37252(62,9 \%)$ stanovnika doseljeno je. Broj stanovnika na prostoru Gradske četvrti Sesvete prema popisu stanovništva iz 2011. iznosio je 70009 stanovnika, od čega u samom naselju Sesvete 54085 stanovnika. ${ }^{9}$ Takav rast stanovništva donio je brojne promjene u prostornoj strukturi naselja i širenju područja Sesveta uz glavne prometne pravce, što je rezultiralo i brojnim društvenim i kulturološkim promjenama.

\section{Narodna knjižnica Sesvete od 1956. do 1972. godine}

Od 1945. do 1960. godine narodne knjižnice osnivaju se u velikom broju, obično na temelju volonterskog rada, bez sustavnog plana i financijskih uvjeta za rad. ${ }^{10}$ Poslije Drugog svjetskog rata, 1946. godine, u Sesvetama se počelo raditi na osnivanju javne knjižnice koja je najprije djelovala na volonterskoj i amaterskoj osnovi u okviru pjevačkog društva „Bratstvo i jedinstvo“ ${ }^{11}$ Narodni odbor općine Sesvete upisao je Narodnu knjižnicu Sesvete u registar ustanova Skupštine općine Sesvete po rješenju broj 5136/1956. od 31. srpnja 1956. godine. ${ }^{12} \mathrm{U}$ zgradi Kurije na adresi Trg Marijana Badela 5 Narodna knjižnica Sesvete djelovala je od 1958. do 1964. godine. Rad se odvijao u dvjema prostorijama u kojima su bili smješteni odjel za odrasle i dječji odjel i čitaonica, a fond knjižnice bio je 2500 knjiga. Prednost za rad knjižnice bila je u tome što se zgrada Kurije nalazi u centru Sesveta, a nedostatak je bio njezin smještaj na prvom katu bez izravnog ulaza.

\footnotetext{
Usp. Šišak, I. Utjecaj doseljavanja na funkcionalno-prostornu transformaciju Gradske četvrti Sesvete: diplomski rad. Prirodoslovno-matematički fakultet, 2018. [citirano: 2021-01-06]. Dostupno na: https://repozitorij.pmf.unizg.hr/islandora/object/pmf:4770.

8 Usp. Antić, N. Kretanje stanovništva Grada Zagreba s posebnim osvrtom na doseljavanje u razdoblju 1991.- 2001. // Migracijske i etničke teme 17(2001), str. 287-309.

9 Državni zavod za statistiku. Popis stanovništva, kućanstava i stanova 2011. [citirano: 202110-05]. Dostupno na: https://www.dzs.hr.

10 Usp. Stipanov, J. Povijest knjižnica i knjižničarstva u Hrvatskoj. Zagreb: Školska knjiga, 2015. Str. 224-245.

11 Usp. Horjan, I. Javno priznanje knjižnici Sesvete. // Sesvetske novine 6, 56(1975), str. 6.

12 Arhiva Knjižnice Sesvete. Rješenje upisa u registar ustanova.
} 
Izvještaj o radu knjižnice govori da je 1957. godine knjižnica imala 121 člana, rok posudbe knjiga bio je dva tjedna, a rad čitaonice otežavao je nedostatak drva i neredovita opskrba novinama. ${ }^{13}$ Zapisnik o radu Upravnog vijeća iz 1959. godine govori o nemogućnosti organiziranja pokretnih knjižnica, izložaba i književnih večeri zbog oskudnih materijalnih sredstava, kao i o potrebi da se za knjižnicu osiguraju odgovarajuće prostorije u novom domu kulture. Također se problematizira potreba zapošljavanja knjižničara s obzirom na još uvijek premali broj čitača. Navodi se potreba nabavljanja beletristike, ali i ideološko političke i popularno znanstvene literature držeći se smjernica za nabavu knjiga. ${ }^{14}$ Do 1960. godine Narodnom knjižnicom i čitaonicom Sesvete upravljao je sedmeročlani odbor (od toga je jedan član vodio blagajničke poslove, a jedan je uz honorar obavljao nadzor u čitaonici). Posudbu knjiga dva puta tjedno obavljala je volonterka, a društveno-politički odjel još nije proradio, ali su se za njegovo osnivanje obavljale pripreme. ${ }^{15}$

Pravni temelji za rad i razvoj svih vrsta knjižnica postavljeni su 1960. godine donošenjem Zakona o bibliotekama. Od tada se započinje sa stručnim označavanjem knjiga, uvođenjem stručnog rasporeda knjiga na policama, kao i sa slobodnim pristupom knjigama u prostoru knjižnica. ${ }^{16}$ Narodna knjižnica i čitaonica Sesvete tijekom 1960. godine započinje s organizacijom rada pokretnih knjižnica u osnovnim školama Adamovec i Sesvetski Kraljevec. Fond knjiga te godine iznosi 4500 svezaka, a članstvo uglavnom čine djeca i omladina. Otvaranje čitaonice u Kašini i prelazak na decimalnu klasifikaciju knjižnog fonda u Narodnoj knjižnici Sesvete, dovelo je do zapošljavanja jednog stručnog radnika i jednog honorarnog djelatnika u knjižnoj stanici. Prva direktorica Narodne knjižnice Sesvete bila je Biserka Kovačević. ${ }^{17}$ Tijekom 60 -ih godina za Narodnu knjižnicu Sesvete poslove matične knjižnice obavljala je Gradska knjižnica u Zagrebu. Na sjednici savjeta Narodne knjižnice i čitaonice Sesvete u prosincu 1960. godine prisustvovala je Višnja Vuković (upraviteljica Gradske knjižnice u Zagrebu), koja je iznijela smjernice za daljnji rad knjižnice. Smjernice su se odnosile na upotpunjavanje mreže knjižnica na području općine Sesvete i otvaranje knjižnih stanica u Sesvetskom Kraljevcu, Kašini i Adamovcu te na organizaciju rada pokretnih knjižnica u svim školama u općini Sesvete. Dalje se navodi da je za Narodnu knjižnicu Sesvete potrebno pronaći prikladan prostor koji bi imao izravan ulaz prizemno s ceste, kao i prostor za čitaonicu, dječji odjel, sobu za katalogizaciju i spremišnu prostoriju. S

13 Arhiva Knjižnice Sesvete. Zapisnik sjednice upravnog odbora Narodne čitaonice i knjižnice u Sesvetama.

14 Usp. Isto.

15 Usp. Grgić, S. Narodne knjižnice grada Zagreba. // Vjesnik bibliotekara Hrvatske 8 (1962), 12, str. 35-47.

16 Zakon o bibliotekama. // Vjesnik bibliotekara Hrvatske 6, 3/4(1960), str. 75-81.

17 Arhiva Knjižnice Sesvete. Zapisnik sjednice upravnog odbora Narodne čitaonice i knjižnice u Sesvetama. 
obzirom na broj stanovnika u općini Sesvete, plan je bio da knjižnica ima knjižni fond od 20000 knjiga te slobodan pristup knjigama. S obzirom na broj djelatnika, predviđeno je zaposliti više djelatnika, i to jednog djelatnika koji bi bio upravitelj knjižničar, jednog knjižničara za pokretne knjižnice i propagandu i jednog knjižničara za dječji odjel. Savjet Narodne knjižnice i čitaonice Sesvete razmatrao je te smjernice i jednoglasno ih prihvatio. ${ }^{18}$ Od 1961. godine Skupština općine Sesvete ponovno utvrđuje status Knjižnice kao samostalne ustanove i određuje ju za matičnu knjižnicu na području općine. Kao što je poznato, matične knjižnice uz svoje redovne poslove rade poslove od zajedničkog interesa za knjižnice na određenom području te brinu o stručnom radu tih knjižnica i stručnom usavršavanju djelatnika. ${ }^{19} \mathrm{U}$ prosincu 1963. godine donesen je Sedmogodišnji plan razvoja Knjižnice, i tim je planom na području općine Sesvete bilo predviđeno pet stalnih knjižnica u većim naseljima općine. Do tada su bile otvorene knjižne stanice u Vugrovcu i Kašini Donjoj, a potrebno je bilo još otvoriti i u Sesvetskom Kraljevcu, Kašini i Adamovcu. Takva se mreža knjižnih stanica činila neučinkovitom, pa je Savjet Narodne knjižnice Sesvete donio odluku da se u tim mjestima težište prebaci na čitaonicu, a da knjižnice djeluju kao pokretne. Posao oko izdavanja knjiga i propagande obavljali bi informatori iz matične knjižnice, a pitanje dežurstva u čitaonicama rješavalo bi se u dogovoru s mjesnim zajednicama u određenim mjestima. Narodna knjižnica Sesvete od 20. ožujka 1964. smještena je u nove prostorije Doma kulture, tada na adresi Trg Marijana Badela $6,{ }^{20} \mathrm{u}$ kojima se i danas nalazi. Zgrada Doma kulture izvedena je prema projektima arhitekta Kazimira Ostrogovića. ${ }^{21}$ Knjižnica je na korištenje dobila $82 \mathrm{~m}^{2}$ prostora, i u tom prostoru djelovala je do 1987. godine. U istim prostorijama bila je smještena knjižnica za djecu i za odrasle s čitaonicom, pa knjižnica tada problem skučenog prostora rješava organizacijom posla u dvjema smjenama. Od 1. rujna 1965. knjižnica radi cijeli dan (za djecu do 17 sati, a za odrasle od 17 do 19 sati). Ni takva organizacija nije bila dovoljna da se izbjegne gužva i omogući informatoru da se posveti svakom korisniku. Opisani se prostor pokazao nedostatnim za nagli razvoj općine i broja stanovnika, pa se nametnula potreba za novim prostorom za pionirsku knjižnicu. Uz novi prostor Narodna knjižnica Sesvete dobila je dva stručna radnika, od kojih je jedna bila direktorica knjižnice, Gordana Popović. ${ }^{22}$ Tijekom 1966. godine otvorena je treća knjižna stanica u Sesvetskom Kraljevcu, a u Vugrovcu i Kašini Donjoj došlo je do poteškoća u radu uslijed neodgovarajućeg prostora. U tvornici „Marijan Badel“" postojala je pokretna knjižnica, a 1967. godine otvorena je pokretna

18 Arhiva Knjižnice Sesvete. Zapisnik sa sjednice savjeta Narodne knjižnice i čitaonice Sesvete 29. 12. 1960.

19 Zakon o bibliotekama. // Vjesnik bibliotekara Hrvatske 6, 3/4 (1960), str. 75-81.

20 Sadašnji naziv je Trg Dragutina Domjanića.

${ }^{21}$ Arhiva Knjižnice Sesvete. Osnovna radna organizacija za projektiranje i srodne tehničke usluge: Nadogradnja doma kulture Sesvete.

22 Arhiva Knjižnice Sesvete. Izvještaj o radu Narodne knjižnice Sesvete za 1964. godinu. 
knjižnica u tvornici „Prigorka“, a planirala se otvoriti i u pogonu „Rade Končar“. Za tvornice je bila preporuka da se koriste pokretnom knjižnicom, a tvornica PIK „Sljeme“ imala je knjižnicu koja je djelovala u suradnji s općinskom matičnom knjižnicom. ${ }^{23} \mathrm{U}$ 1968. godini otvorena je knjižna stanica Adamovec povodom obilježavanja 35. godišnjice smrti pjesnika Dragutina Domjanića. ${ }^{24}$ Izvještaj o radu Narodne knjižnice Sesvete za 1967. godinu govori kako je prostor u kojem djeluje knjižnica postao pretijesan za rastući fond, a u čitaonicu je dodana nova polica za knjige te je time dodatno smanjen i prostor čitaonice. ${ }^{25}$ Od 1963. do 1968. godine Knjižnica je povećala broj radnih sati za korisnike na 48 sati tjedno. U petogodišnjem razdoblju povećana je nabava knjiga, pa tako 1968. godine fond broji 13000 svezaka, što iznosi 0,5 knjige po stanovniku općine, a normativ za narodne knjižnice naglašava minimum od jedne knjige po stanovniku područja na kojem knjižnica djeluje. Kontinuirano se upisuje sve više odraslih članova, no učenici su najbrojniji članovi. U planovima i programima rada knjižnice za sljedeću godinu ponavlja se važnost nabave prikladnog prijevoznog sredstva kako bi pokretne knjižnice mogle stići na dovoljan broj punktova. ${ }^{26}$ Izvještaj o radu Knjižnice kao i tadašnji članci u Sesvetskim novinama govore o organiziranim književnim večerima povodom „Mjeseca knjige“, susretima s poznatim dječjim piscima i novim akcijama u knjižnici, kao i novim naslovima. ${ }^{27}$ Položaj narodnih knjižnica u Hrvatskoj znatno je poboljšan donošenjem Zakona o sredstvima društvenih fondova za unapređenje kulturnih djelatnosti iz 1968. godine. Osnivaju se fondovi za kulturu pri društveno-političkim zajednicama, a knjižnice dobivaju redovitija sredstva za knjige i materijalne potrebe, što dovodi do razvoja mreža narodnih knjižnica. ${ }^{28}$

\section{Narodno sveučilište Sesvete - knjižnica i čitaonica}

Od 1970. godine započinje srednjoročno i dugoročno planiranje razvoja knjižničarske djelatnosti. Tada je izrađen prvi Prijedlog petogodišnjeg plana razvoja javnih knjižnica u SR Hrvatskoj 1971 - 1975. godine, a slijedili su planovi za petogodišnja razdoblja do 1990 . godine. ${ }^{29}$ Prema Prijedlogu plana razvoja knjižnice u općini Sesvete od 1971. do 1975. godine bilo je potrebno: ojačati mrežu knjižnica na području općine, proširiti broj korisnika, povećati broj knjiga, povezati se s Gradskom knjižnicom u Zagrebu radi obavljanja zajedničkih stručnih

\footnotetext{
23 Arhiva Knjižnice Sesvete. Izvještaj o radu Narodne knjižnice Sesvete za 1967. godinu.

24 Arhiva Knjižnice Sesvete. Izvještaj o radu Narodne knjižnice Sesvete za 1968. godinu.

25 Arhiva Knjižnice Sesvete. Izvještaj o radu Narodne knjižnice Sesvete za 1967. godinu.

26 Arhiva Knjižnice Sesvete. Izvještaj o radu Narodne knjižnice Sesvete za 1968. godinu.

27 Arhiva Knjižnice Sesvete. Izvještaj o radu Narodne knjižnice Sesvete za 1970. godinu.

28 Usp. Gomerčić, N. Narodne knjižnice u Hrvatskoj jučer, danas i sutra. // Vjesnik bibliotekara Hrvatske 40, 12(1997), str. 82.

29 Usp. Isto.
} 
poslova, poboljšati knjižnični prostor u Sesvetama te nabaviti i organizirati bibliobusnu službu. ${ }^{30}$ Prema Zakonu o izmjenama i dopunama Zakona o bibliotekama od 8. veljače 1965. godine, samostalne knjižnice mogu se spojiti u jednu ustanovu ako se spajanjem osiguraju povoljniji uvjeti za njihov rad. O integraciji Narodne knjižnice i Narodnog sveučilišta u Sesvetama više su puta raspravljali radna zajednica i stručni kolegij knjižnice. Prvi put 1967. godine iznesen je prijedlog za integraciju Narodnog sveučilišta i Narodne knjižnice Sesvete, ali tada je taj prijedlog odbijen. ${ }^{31} \mathrm{U}$ prosincu 1971. godine referendumom je donesena odluka Radne zajednice Narodne knjižnice da se Narodna knjižnica iz Sesveta spaja s Narodnim sveučilištem iz Sesveta, Klubom omladine i Centrom za informacije u ustanovu pod nazivom Ustanova za kulturu, obrazovanje i informacije. Cilj te integracije bio je stvaranje povoljnijih uvjeta za rad na obrazovanju odraslih i omladine, za razvoj mreže knjižnica, bogatiji kulturno umjetnički život građana, očuvanje povijesnih vrijednosti i učinkovitije informiranje građana. Nova ustanova pod nazivom Narodno sveučilište započinje s radom 4. veljače 1972. godine, a sjedište je ustanove Trg Marijana Badela 6. Od tada knjižnica djeluje kao organizacijska jedinica Narodnog sveučilišta s pet knjižnih stanica - Vugrovec, Kašina, Adamovec i Sesvetski Kraljevec i jednom knjižnom stanicom u tvornici „Rade Končar". Zbog skučenog prostora čitaonice, knjižnica nije mogla znatnije razvijati svoju aktivnost. ${ }^{32}$ U studenom 1974. godine otvorena je knjižna stanica u Dupcu. Od 1975. godine Matična služba Gradske knjižnice u Zagrebu provodi anketiranje knjižnica grada prikupljajući najznačajnije podatke o njihovom radu u prethodnoj godini radi analiza o stanju knjižnične mreže narodnih knjižnica za izradu srednjoročnih i dugoročnih planova razvoja. Knjižnica Sesvete je 1975. godine imala 3000 članova te je za svoj rad na razvijanju knjižnične djelatnosti dobila republičko priznanje „Pavao Markovac“. 33

U Planu i programu rada Narodnog sveučilišta Sesvete za 1979. godinu napominje se da se u nadolazećem razdoblju mora riješiti problem prostora knjižnice, odnosno odvojiti dječji odjel od odjela za odrasle kako bi se osigurao normalan rad s korisnicima i dobio odgovarajući prostor za čitaonicu, te da je neophodno osigurati sredstva za kupnju namještaja knjižnici Sesvete i knjižnici u Dupcu. Prostor središnje općinske knjižnice postao je premalen za bilo kakve aktivnosti osim nužnog smještaja knjižnog fonda, a problem prostora postojao je i u Dupcu, gdje su prostoriju u kojoj je smještena knjižnica koristile i druge organizacije, pa je sigurnost knjižnog fonda dovedena u pitanje. ${ }^{34}$ Modeli financiranja mijenjaju se u

30 Arhiva Knjižnice Sesvete. Prijedlog plana rada Narodne knjižnice Sesvete 1970-1975. godine.

31 Arhiva Knjižnice Sesvete. Prijedlog za integraciju Narodnog sveučilišta i Narodne knjižnice Sesvete.

32 Arhiva Knjižnice Sesvete. Odluka Radne zajednice Narodne knjižnice Sesvete.

33 Arhiva Knjižnice Sesvete. Narodno sveučilište Sesvete: Izvještaj o radu za 1975. godinu.

34 Arhiva Knjižnice Sesvete. Narodno sveučilište Sesvete: Izvještaj o radu za 1978. godinu 
skladu s promjenama u državi i izmjenama ustroja lokalne uprave. Razvoju većine narodnih gradskih ili općinskih knjižnica doprinosi njihovo samostalno djelovanje. Do promjena samostalnog statusa dolazi tijekom sedamdesetih godina kada su se knjižnice udruživale u centre za kulturu i obrazovanje, što je gotovo svugdje uzrokovalo nazadovanje u radu i razvoju tih knjižnica. ${ }^{35}$

\section{Knjižnice grada Zagreba: Knjižnica Sesvete}

Od 1. ožujka 1986. godine Knjižnica Sesvete kao središnja općinska knjižnica (uz područnu knjižnicu Dubec i knjižne stanice Novo Brestje, Sesvetska Sela, Sesvetski Kraljevec i tvornica „Sljeme“) počinje djelovati u sastavu Knjižnica grada Zagreba. Na prostoru općine jedna je narodna knjižnica središnja, a oko nje se stvara mreža koju čine ostali tipovi knjižnica manji od središnje, a u svrhu poboljšanja knjižničnih usluga stanovništvu. ${ }^{36}$ Fond knjiga tada broji 39554 sveska, od čega je oko 7000 svezaka u knjižnici Dubec, a 300 do 500 svezaka nalazi se u svakoj od knjižnih stanica. Najveći dio fonda nalazio se u središnjoj knjižnici u slobodnom pristupu. Knjižnica tada ukupno ima 4878 korisnika, od čega 2660 djece i 2218 odraslih. Knjižnica Sesvete u sastavu Knjižnica grada Zagreba tijekom 1987. godini započinje uređivati novi prostor knjižnice za djecu i omladinu na Selčini te uređivati depo za potrebe središnje knjižnice u zgradi Kulturnog centra. Dobiven je prostor bivšeg skladišta „Crvenog križa“ koji se nalazio u suterenu zgrade Narodnog sveučilišta, veličine $54 \mathrm{~m}^{2}$. Predviđeno je da će se nakon završene adaptacije taj prostor koristiti kao odjel nabave i obrade te spremište za knjige. U prvom polugodištu 1988. godine prostor središnje općinske knjižnice Sesvete povećan je za $55 \mathrm{~m}^{2}$, tako da tada ukupan prostor središnje općinske knjižnice iznosi 180 $\mathrm{m}^{2}$. Bila je potrebna adaptacija prostora središnje knjižnice, za što je bilo potrebno izraditi idejni projekt adaptacije i izvršiti početne radove. Matična služba Knjižnica grada Zagreba predložila je da se prostor organizira pomoću funkcionalnih cjelina: ulaz i prijem stranaka, dječji odjel, slobodan pristup za odrasle, čitaonica dnevne štampe te nekoliko radnih mjesta za individualan rad. ${ }^{37}$

Nakon prostornog proširenja prestala je raditi knjižna stanica u Sesvetskom Kraljevcu (zbog neodgovarajućih prostornih uvjeta) te knjižnica u radnoj organizaciji „Sljeme“" zbog stečajnog postupka. Raskidom ugovora u radnoj organizaciji „Sljeme“ knjižni fond od 3209 svezaka vraćen je Knjižnici Sesvete. S obzirom na zatvaranje tih knjižnih stanica, Knjižnica Sesvete predložila je bibliobusnoj službi otvaranje bibliobusnih stajališta na sjevernom području općine Sesvete i to

\footnotetext{
35 Usp. Stipanov, J. Nav. dj, str. 229.

36 Usp. Upute za poslovanje narodnih knjižnica. / uredila A. Malnar. Zagreb: Knjižnice grada Zagreba, 1996. Str. 13.

37 Arhiva Knjižnice Sesvete. Knjižnice grada Zagreba: Izvještaj stručnih suradnika Matične službe za planiranje i izgradnju bibliotečnih prostora.
} 
u mjesnim zajednicama Sesvetski Kraljevec i Soblinec. Rad u skučenom prostoru Knjižnice Sesvete bivao je sve teži i nemoguće je bilo nastaviti s organizacijom izložbi i tribina. ${ }^{38}$

Knjižnica Selčina namijenjena djeci i omladini započela je s radom 1. ožujka 1989. godine. Tada je to bio jedini knjižnični prostor za djecu i mlade u Sesvetama. U godišnjem izvještaju o radu Knjižnice Sesvete naglašena je potreba nastavka rada dječjeg odjela u središnjoj knjižnici bez obzira na uvjete. Za rad i postignute rezultate u razvoju bibliotečne djelatnosti Knjižnici Sesvete je u svibnju 1989. godine dodijeljena nagrada „Pavao Markovac“. 39

Prema Standardima za narodne knjižnice u Republici Hrvatskoj za područje od 60000 stanovnika središnja knjižnica morala bi imati $1860 \mathrm{~m}^{2}$, odnosno $31 \mathrm{~m}^{2}$ na svakih 1000 stanovnika. Sesvete su u to vrijeme najugroženiji dio grada Zagreba $\mathrm{s}$ aspekta prostora narodnih knjižnica, $\mathrm{s}$ obzirom na to da prema istom računanju imaju svega 4,85 m² na 1000 stanovnika ${ }^{40} \mathrm{Krajem} 1989$. godine Knjižnici Sesvete dodijeljen je, u sklopu zgrade Narodnog sveučilišta Sesvete, suterenski prostor napuštene kuglane veličine $250 \mathrm{~m}^{2}$. Tijekom rata u njemu je bila smještena ratna bolnica, a tek 1997. godine knjižnica ga je dobila natrag za korištenje. U međuvremenu započinju pregovori da se i susjedni prostor nekadašnjeg omladinskog kluba od $230 \mathrm{~m}^{2}$ spoji s prostorom bivše kuglane i također dodjeli knjižnici. Objedinjenjem postojećeg prostora s novododijeljenim prostorom sveukupna površina knjižnice iznosila bi $600 \mathrm{~m}^{2} .^{41}$ Prilikom adaptacije Knjižnice prostor se planirao u skladu sa Standardima za narodne knjižnice Republike Hrvatske tako da postoje funkcionalne cjeline: ulaz i prijem korisnika, čitaonica tiska, posudbeno-informativni odjel za odrasle s mjestom dežurnog knjižničara, odjel ili prostor za studijski rad, odjel za AV zbirku, odjel za djecu i mladež, radna soba za voditelja, prostor za interni stručni rad, prostor za knjižničare kada ne rade sa strankama, spremište knjiga s prostorom za tehničku obradu i izložbeni prostor. ${ }^{42}$ Proširena i adaptirana Knjižnica Sesvete otvorena je 28. svibnja 1999. godine. Prizemni prostor u kojem je do tada bila Knjižnica postao je galerijski prostor i čitaonica tiska te prostor za različite kulturne aktivnosti, dok se u suterenu nalazi glavnina prostora koji je opremljen staklenom stijenom i velikim prozorima te je prikladno osvijetljen. Prijem korisnika odvija se na zajedničkom centralnom pultu, a iza pulta nalazi se odjel za najmlađe. Glavninu prostora lijevo od ulaza čini slobodan pristup za učenike nižih i viših razreda osnovne škole i mladež. Uz prozore je smještena studijska čitaonica, a u prostoru bivše kuglane smješten je slobodan pristup za odrasle koji je drvenom pregradom odijeljen od spremišta. Služba nabave i obra-

\footnotetext{
38 Arhiva Knjižnice Sesvete. Izvještaj o radu za 1988. godinu.

39 Arhiva Knjižnice Sesvete. Izvještaj o radu za 1989. godinu.

40 Arhiva Knjižnice Sesvete. Stanje narodnih knjižnica na području Sesveta.

${ }^{41}$ Arhiva Knjižnice Sesvete. Knjižnica Sesvete uspješna adaptacija nenamjenskog prostora.

42 Arhiva Knjižnice Sesvete. Arhitektonsko građevinski projekt.
} 
de smještena je izdvojeno. Nakon proširenja i adaptacije Knjižnica Sesvete ima $650 \mathrm{~m}^{2}$ suvremeno opremljenog knjižničnog prostora dostupnog korisnicima svih uzrasta. ${ }^{43}$ Iz izvještaja o radu Knjižnice Sesvete za 2000. godinu vidljiv je rast redovne djelatnosti. Broj aktivnih članova tada je 12 393, dok je stanje knjižnog fonda 52173 svezaka. Održano je 1444 akcija za djecu koje su imale 12566 posjetitelja. Poslovanje u Knjižnici Sesvete kompjutorizirano je od listopada 2000. godine, kada se počinje koristiti Informacijski mrežni sustav ZaKi s potpuno informatiziranim poslovima nabave, obrade i posudbe knjižnične građe. ${ }^{44}$ Tijekom 2005. godine Knjižnici Sesvete oduzet je prostor u kojem se nalazio odjel nabave i obrade knjiga. Budući da nije osiguran zamjenski prostor, odjel nabave i obrade smješten je unutar postojećeg knjižničnog prostora reorganizacijom istog. U prosincu 2012. godine otvoren je novi ogranak Knjižnice Sesvete - Knjižnica Jelkovec, kao samostalan objekt s četiri etaže i $900 \mathrm{~m}^{2}$. Tako se knjižnični prostor na području Gradske četvrti Sesvete povećao i iznosi ukupno $1746 \mathrm{~m}^{2}$. Potreban knjižnični prostor prema Standardima za narodne knjižnice u Republici Hrvatskoj, a s obzirom na broj stanovnika gradske četvrti Sesvete, trebao bi biti $2170 \mathrm{~m}^{2}$. U izvješću o radu za 2013. godinu Knjižnica Sesvete s ograncima ima knjižni fond od 104303 sveska, posudbu od 157708 knjiga, a ukupno je 13484 aktivna korisnika. Održano je 2512 akcija za djecu s ukupno 27674 posjetitelja.

Prema Izvještaju o radu Knjižnice Sesvete za 2019. godinu ukupni fond knjižne i neknjižne građe iznosi 122350 svezaka, a broj aktivnih članova je 15 213, dok je u 2020. godini ukupni fond 126161 jedinica s 12870 aktivnih članova. Usporedbom podataka iz Izvještaja o radu Knjižnice Sesvete za 2000. godinu i trenutnih podataka, vidljivo je da veličina fonda knjižnice raste i približila se standardu od 1,5 knjige po stanovniku na području djelovanja knjižnice. Sukladno tome povećava se i broj aktivnih korisnika knjižnice. Dugogodišnja voditeljica Knjižnice Sesvete bila je Dubravka Prlić (1982. - 2014.), zatim Biserka Gašparac (2014. -2018.), a od 2018. godine voditelj je Knjižnice Sesvete Ivan Babić.

\subsection{Knjižnica Sesvete kroz knjižnične programe i usluge}

Narodna knjižnica osigurava pristup informacijama i znanju svim članovima zajednice te ima dvije jednako važne uloge. Jedna je osiguravanje građe na različitim medijima, a druga pružanje usluga kako bi se zadovoljile obrazovne i informacijske potrebe pojedinca. Njima treba pridodati i potrebe vezane uz slobodno vrijeme i cjeloživotno učenje te osobni razvoj pojedinca, ali i lokalne zajednice. ${ }^{45}$

\footnotetext{
43 Arhiva Knjižnice Sesvete. Knjižnica Sesvete uspješna adaptacija nenamjenskog prostora.

44 Arhiva Knjižnice Sesvete. Pregled ostvarenja programa rada zagrebačkih narodnih knjižnica u 2000. godini.

45 Usp. IFLA-ine smjernice za narodne knjižnice. 2. hrv. izd. (prema drugome izmijenjenom izd. izvornika). / uredile C. Koontz i B. Gubbin. Zagreb: Hrvatsko knjižničarsko društvo, 2011. Str.
} 
Imajući u vidu te potrebe, u Knjižnici Sesvete u listopadu 2001. godine pokrenut je Kulturni četvrtak u Sesvetama koji neprekidno djeluje do danas. Započeo je kao tribina koja se održavala dva puta mjesečno, a danas ima brojne aktivnosti koje se odvijaju u mreži sesvetskih knjižnica. ${ }^{46}$ Već u prvim godinama tribine uspostavljena je suradnja s većom grupom sesvetskih pjesnika, što je rezultiralo zbornikom poezije „Sesvetski oblok“, objavljenim 2006. godine. Uz 100. tribinu Kulturnog četvrtka u Sesvetama, 2008. godine održan je „Mali sesvetski pjesnički maraton“, čime je započeo zaseban projekt „Sesvetski pjesnički maraton“ koji se održava jednom godišnje i predstavlja najmasovnije pjesničko okupljanje u Hrvatskoj.

$\mathrm{Na}$ 10. sesvetskom pjesničkom maratonu 2017. godine Tonko Maroević simbolično je proglasio Knjižnicu Sesvete Republikom stiha te je pokrenut novi projekt popularizacije poezije - Stihotron. ${ }^{47}$

U prostoru Knjižnice Sesvete od 1976. godine održavaju se izložbe. Godine 1998. dotadašnji prostor Knjižnice postaje izložbeni prostor u kojem je ujedno i čitaonica tiska, a od 2003. godine nosi naziv Galerija Oblok. ${ }^{48}$

Od osnutka Dječjeg odjela u Gradskoj knjižnici u Zagrebu 1950. godine ističe se važnost osmišljavanja i provođenja knjižničnih usluga za djecu i mladež u svrhu poticanja čitanja i odgoja budućih korisnika knjižnica. Svojim radom i organizacijom Knjižnica Sesvete to podržava i kontinuirano razvija, počevši od osnivanja pokretnih knjižnica u školama na području općine Sesvete i provođenjem pedagoških akcija u knjižnim stanicama, čime je također nadomješten nedostatak knjižničnog prostora i aktivnosti Odjela za djecu i mlade od osnutka Knjižnice Sesvete do otvaranja Knjižnice Selčina. Nakon adaptacije 1998. godine Knjižnica Sesvete dobiva suvremeno opremljen Odjel za djecu i mlade koji provodi kvalitetne i raznovrsne programe i projekte.

\subsection{Knjižnica Dubec}

Naglim razvojem naselja Brestje, Retkovec, Sopnica i Trnovčica ukazala se potreba za otvaranjem knjižnice i čitaonice. Knjižna stanica Dubec otvorena je 15. listopada 1974. kao dio Knjižnice Sesvete. Smještena je u prostoru Mjesne zajednice koju su koristili predstavnici Mjesne zajednice i Matičnog ureda te brojne druge organizacije. Kada se prostor Mjesne zajednice koristio u druge svrhe

\footnotetext{
14.

46 Knjižnice grada Zagreba. Kulturni četvrtak u Sesvetama. [citirano: 2121-07-08] Dostupno na: http://www.kgz.hr/hr/knjiznice/knjiznica-sesvete/kulturni-cetvrtak-u-sesvetama/7724.

47 Babić, I.; M. Bily; I. Klak Mršić. Sesvetski pjesnički maraton: Istraživanje zadovoljstva korisnika. // Vjesnik bibliotekara Hrvatske 62, 2(2019), str. 227-246. [citirano: 2021-10-05]. Dostupno na: https://www.hkdrustvo.hr/vjesnik-bibliotekara-hrvatske/index.php/vbh/article/view/776. 48 Knjižnice grada Zagreba. Galerija Oblok. [citirano: 2021-04-08]. Dostupno na: http://www. kgz.hr/hr/knjiznice/knjiznica-sesvete/galerija-oblok/o-galeriji-53775/53775.
} 
zavjesom su se pregrađivale knjige od ostatka prostora. U početku je Knjižnica bila otvorena samo tri puta tjedno po dva sata, da bi s porastom broja članova 1979. godine započeo svakodnevni rad u jednoj smjeni. Od ponedjeljka do srijede Knjižnica radi popodne, a od četvrtka do subote u jutarnjoj smjeni, tako je ostalo do danas. Knjiga inventara Knjižnice Dubec uvedena je 1979. godine a tada je knjižni fond brojio oko 2000 knjiga. ${ }^{49}$ Tijekom godina rada Knjižnice Dubec u prostoru Mjesne zajednice održani su brojni sastanci Knjižnica grada Zagreba i Mjesne zajednice Dubec na kojima se razgovaralo o načinima korištenja i održavanja prostora koji Knjižnica koristi. Početkom 1990-ih Knjižnice grada Zagreba slale su molbe Gradskom uredu za planiranje i urbanizam da se prilikom gradnje naselja Poljanice predvidi prostor za potrebe Knjižnice Dubec. ${ }^{50} \mathrm{Na}$ ponovljenu zamolbu za novim knjižničnim prostorom Gradski fond za kulturu predlagao je da se uvede bibliobusna služba te da se izradi radni materijal o stanju i potrebama za prostor narodnih knjižnica na području Sesveta. ${ }^{51}$ Knjižnice grada Zagreba i grad Zagreb sklopili su ugovor o zakupu poslovnog prostora ukupne površine $79,80 \mathrm{~m}^{2}$ koji se koristi za knjižničnu djelatnost, a od čega $32 \mathrm{~m}^{2}$ zauzimaju police i radni stol knjižničara. Nakon uređenja 1996. godine Knjižnica Dubec postaje ogrankom Knjižnice Sesvete u prostoru od $80 \mathrm{~m}^{2}$ u kojem djeluje odjel za djecu i mladež i odjel za odrasle. Knjižnica je za korisnike otvorena 36 sati tjedno i ima dva stručna djelatnika. ${ }^{52}$ Za obradu novih knjiga i interni rad knjižnice Služba za mjesnu samoupravu, Odjel za rad gradskih četvrti, 2007. godine odobrio je Knjižnici korištenje jednog ureda i sanitarnog čvora u domu bivše Mjesne zajednice Dubec, i to ponedjeljkom, utorkom i srijedom od 12 do 19 sati te četvrtkom, petkom i subotom od 8 do 14 sati. ${ }^{53}$ Dogovorom između Gradske četvrti Donja Dubrava i Knjižnica grada Zagreba Knjižnica Dubec je 2010. za potrebe čitaonice tiska dobila na korištenje prostor hodnika, a sve prostorije koje koristi knjižnica zaključavaju se kada knjižnica nije otvorena za korisnike, te od tada Knjižnica djeluje na $120 \mathrm{~m}^{2} .{ }^{54}$

Dugogodišnji pregovori oko prostora Knjižnice Dubec utjecali su na mogućnosti provođenja knjižničnih programa. Pedagoško-animatorska akcija za djecu „Pričanje priča“ pokrenuta je još 1979. godine u knjižnoj stanici Dubec. Od svojih početaka do danas Knjižnica Dubec nastojala je osigurati pristup informacijama i uslugama svojim korisnicima. Aktivno sudjelujući u brojnim projektima Knjižnica grada Zagreba, provode se različiti kulturni i edukativni programi za korisnike svih dobnih skupina. Koordinatorica Knjižnice Dubec od samih početaka do 2010. godine bila je Marija Gostijanović. Od 2010. godine do 2017. godine u Knjižnici

\footnotetext{
49 Arhiva Knjižnice Sesvete. Pregled poslovanja Knjižnice Dubec od 1974. do 1982. godine.

50 Arhiva Knjižnice Sesvete. Problem prostora Knjižnice Dubec.

51 Arhiva Knjižnice Sesvete. Knjižna stanica Dubec.

52 Arhiva Knjižnice Sesvete. Stanje narodnih knjižnica na području Sesveta.

53 Arhiva Knjižnice Sesvete. Izvještaj o radu Knjižnice Dubec za 2007. godinu.

54 Arhiva Knjižnice Sesvete. Promemorija Knjižnice Dubec.
} 
Dubec izmjenjivali su se stručni djelatnici, a 2017. godine koordinatorstvo preuzima Jelena Pisačić.

\subsection{Knjižnica Selčina}

U prosincu 1984. godine sklopljen je kupoprodajni ugovor između SIZ-a stanovanja Općine Sesvete i Narodnog sveučilišta u Sesvetama za prostor veličine 111,32 $\mathrm{m}^{2}$ u objektu u izgradnji u novom stambenom naselju Selčina u svrhu otvaranja Knjižnice Selčina, ogranka Knjižnice Sesvete. Otvorenje i početak rada Knjižnice Selčina planirao se u lipnju 1987. godine..$^{55}$ U studenom 1985. godine Knjižnice grada Zagreba preuzimaju navedeni prostor jer se Knjižnica Sesvete izdvojila iz Narodnog sveučilišta i postala radna jedinica u sastavu Knjižnica grada Zagreba. Prostor namijenjen Knjižnici sastoji se od dviju prostorija u ukupnoj neto kvadraturi od $115,30 \mathrm{~m}^{2}$. Lijevo od ulaza smještena je garderoba korisnika, a desno je smješten čitaonički prostor za odrasle. Na garderobu se veže manipulativni pult, a uz čitaonicu se nalazi prostor s policama za smještaj knjiga za odrasle. Svojevrsno razgraničenje među odjelima predstavlja prostor za dežurnog informatora. Na kraju prostora predviđenog za omladinski odjel nalazi se čitaonički stol, a uz ulaz u dječji odjel smješteno je računalo. Nasuprot tim sadržajima smještena je mala pozornica u vidu tribine (stepenište) koja ujedno služi za pristup do vrata požarnog izlaza. Prostor ispod pozornice koristi se kao spremište. U dnu prostora dječjeg odjela smještene su police za dječji fond ispred kojih je stolić te korita za slikovnice.$^{56}$ Knjižnica Selčina započela je s radom 1. ožujka 1989. godine kao ogranak Knjižnice Sesvete. Uređena je i opremljena u skladu sa Standardima za narodne knjižnice u Republici Hrvatskoj za ogranak namijenjen djeci i mladima iako ima i odjel za odrasle. Od početka rada Knjižnice sustavno se organiziraju i provode pedagoške aktivnosti za djecu i mlade. Odjel za djecu i mlade ima svrhu stvaranja novih generacija knjižničnih korisnika. ${ }^{57}$ Knjižnica Selčina od 1994. godine sudjelovala je i u realizaciji projekta „Korak po korak do oporavka“, kojim su bila obuhvaćena djeca pogođena ratnim traumama. Biblioterapijske radionice provodile su knjižničarke. ${ }^{58}$ Danas se biblioterapijske radionice koriste kao uspješan alat u radu dramsko-lutkarske grupe Knjižnice Selčina, kao i u programu „Po Sesvetama i Sesvetskom prigorju“.

\footnotetext{
55 Arhiva Knjižnice Sesvete. Program rada za 1987. godinu.

56 Arhiva Knjižnice Sesvete. Žerjavić radna organizacija za projektiranje: uređenje Knjižnice Selčina.

57 Usp. Upute za poslovanje narodnih knjižnica. Nav. dj., str. 93.

58 Usp. Cej, V.; K. Krpan; I. Klak Mršić. Primjena razvojne biblioterapije u radu s djecom i mladima u narodnoj knjižnici. // Vjesnik bibliotekara Hrvatske 61, 1(2018), str. 345-361. [citirano: 2021-10-05]. Dostupno na: https://www.hkdrustvo.hr/vjesnik-bibliotekara-hrvatske/index.php/ vbh/article/view/621/574.
} 
Kako se mijenjalo naselje Selčina, tako se mijenjala i uloga Knjižnice Selčina. Transformacija knjižnice u treći životni prostor naselja, posljedica je rada knjižničara koji osmišljavaju knjižnične aktivnosti u skladu s potrebama lokalne zajednice. Koordinatorica Knjižnice od njezina otvaranja do 2013. godine bila je Gordana Hmelina, a od 2013. godine Knjižnicom koordinira Keti Krpan.

\subsection{Knjižnica Jelkovec}

Naselje Novi Jelkovec kao dio gradske četvrti Sesvete smješteno je južno od gradskog središta i željezničke pruge te sjeverno od Slavonske avenije. Izgradnja naselja započela je 2006. godine, a prvi stanovi useljeni su 2009. godine. Prema popisu stanovništva iz 2011. godine govorimo o 4978 stanovnika, a danas u naselju ima više od 10000 stanovnika. ${ }^{59}$ Knjižnice grada Zagreba dale su prijedlog za osnivanje ogranka Knjižnice Sesvete veličine $200-300 \mathrm{~m}^{2}$ u novom naselju. ${ }^{60} \mathrm{Ali}$ doneseni plan uređenja naselja predvidio je izgradnju Knjižnice kao samostojećeg objekta. Tijekom 2008. godine izrađen je idejni projekt knjižnice, a 2009. godine započela je gradnja objekta. U 2010. godini se putem sastanaka koordinacije pratila izgradnja objekta. Izrađen je projekt informatičke i RIFD tehnologije za knjižnicu i započeta je sustavna nabava knjižnične građe. Zgrada knjižnice projektirana je kao samostojeći objekt površine oko $900 \mathrm{~m}^{2}$, na četiri etaže: podzemna etaža s multimedijskom dvoranom i spremištem za knjige, prizemlje s informacijskim pultom, prvi kat namijenjen je djeci i mladeži, a na drugom je katu odjel za odrasle korisnike. Knjižnica je prema najavama investitora trebala biti gotova 2010. godine. ${ }^{61} \mathrm{U}$ 2011. godini naručen je projekt unutarnjeg uređenja knjižnice, a u veljači 2012. obavljena je primopredaja prostora. ${ }^{62}$ Knjižnica Jelkovec otvorena je 7. prosinca 2012. godine kao prvi samostojeći objekt u mreži Knjižnica grada Zagreba. ${ }^{63}$ Tijekom proteklih godina Knjižnica Jelkovec u suradnji s udrugom Iskra - centar za edukaciju provodila je brojne projekte za djecu i mlade, ali i za odrasle, s ciljem podizanja kvalitete života u naselju. Provođenjem projekta „Književni kulturni lift" nastoji se uključivati umjetnički sadržaj u svakodnevni život. Kao suradnička

59 Mjesni odbor Novi Jelkovec. [citirano: 2021-10-03]. Dostupno na: https://www.zagreb. hr/27-mjesni-odbor-novi-jelkovec/15469.

60 Standardi za narodne knjižnice u Republici Hrvatskoj. // Narodne novine 58, 1071(1999). [citirano: 2021-30-03]. Dostupno na: https://narodne-novine.nn.hr/clanci/sluzbeni/1999_06_58_1071.html.

${ }_{61}$ Usp. Prlić, D. Nova knjižnica u naselju Novi Jelkovec u Sesvetama. // Novosti Hrvatskog knjižničarskog društva 48(2012) [citirano: 2021-03-02]. Dostupno na: https://www.hkdrustvo. $\mathrm{hr} / \mathrm{hkdnovosti} / \mathrm{clanak} / 271$.

62 Opremanje i izgradnja knjižnice: Planiranje i izgradnja Knjižnice Jelkovec. [citirano: 202111-03]. Dostupno na: http://www.kgz.hr/hr/knjiznice/knjiznica-jelkovec/o-knjiznici-7117/opremanje-i-izgradnja-knjiznice/28586.

63 Usp. Klak Mršić, I. Otvorena Knjižnica Jelkovec u mreži Knjižnica grada Zagreba. // Novosti Hrvatskog knjižničarskog društva 58(2013), str. 1 [citirano: 2021-04-02]. Dostupno na: https:// www.hkdrustvo.hr/hkdnovosti/clanak/630. 
knjižnica projekta Američki kutak Zagreb, Knjižnica Jelkovec djeci i mladima nudi knjižnične usluge vezane za primjenu novih tehnologija. Knjižnicom od njezina otvaranja koordinira Iva Klak Mršić.

\section{Zaključak}

Od 1956. do 1972. godine Narodna knjižnica Sesvete bila je samostalna knjižnica, a u sastavu Narodnog sveučilišta Sesvete knjižnica je djelovala od 1972. do 1985. godine. Od 1958. do 1964. godine Knjižnica Sesvete djeluje u zgradi Kurije, a od 1964. godine u zgradi Doma kulture, odnosno danas zgradi Narodnog sveučilišta. Godine 1964. knjižnični prostor iznosio je $82 \mathrm{~m}^{2}$. Završetkom njegove adaptacije 1999. godine Knjižnica je koristila $650 \mathrm{~m}^{2}$ prostora. Godine 2005. izgubila je izdvojeni prostor za odjel nabave i obrade, tako da danas područna

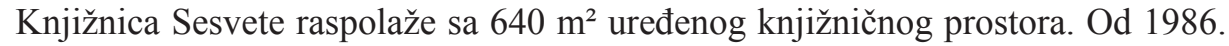
godine Knjižnica Sesvete sa svojim ograncima djeluje kao područna knjižnica u mreži Knjižnica grada Zagreba. Knjižna stanica Dubec otvorena je 1974. godine te bilježi 47 godina djelovanja, a tek posljednjih deset godina koristi $120 \mathrm{~m}^{2}$ knjižničnog prostora. Knjižnica Selčina otvorena je 1989. godine kao ogranak namijenjen svim dobnim skupinama, a prvo desetljeće svoga rada djelovala je kao odjel za djecu i mlade Knjižnice Sesvete. Knjižnica Jelkovec otvorena je 2012. godine i od tada knjižnični prostor u gradskoj četvrti Sesvete iznosi $1764 \mathrm{~m}^{2}$. To je još uvijek ispod propisanih standarda za narodne knjižnice, posebice ako se uzme u obzir da Sesvete bilježe stalan porast stanovništva.

Knjižnica Sesvete kroz tribinu Kulturni četvrtak u Sesvetama njeguje ulogu knjižnice kao mjesta za provođenje slobodnog vremena uz niz raznovrsnih kulturnih događanja namijenjenih građanima s naglaskom na promicanje čitanja i poticanje mladih na pisanje poezije, te je u protekle dvije godine sadržaj tih aktivnosti dostupan i na društvenim mrežama. U redovnim i povremenim knjižničnim aktivnostima nastoji se upoznati građanstvo s pojmom zelene pismenosti i upozoriti na njezinu važnost u lokalnoj zajednici. Knjižnica Selčina nastoji biti prepoznatljivo kulturno i informativno središte provodeći biblioterapijske, lutkarske i dramske radionice i programe za djecu i mladež s ciljem razvijanja čitateljske pismenosti kod najmlađih knjižničnih korisnika. U svrhu nadogradnje knjižničnih usluga i aktivnosti, Knjižnica Dubec provodi različite umjetničke intervencije s ciljem poticanja kritičkog mišljenja u lokalnoj zajednici. Knjižnica Jelkovec kao treći životni prostor u novom naselju svojim uslugama i programima odgovara na potrebe korisnika i svih članova zajednice sa svrhom unapređivanja kvalitete života.

Nedostatak odgovarajućeg knjižničnog prostora Knjižnica Sesvete s ograncima kroz povijest je nastojala kompenzirati osmišljavanjem brojnih knjižničnih programa i usluga raznovrsnog sadržaja namijenjenih korisnicima različite dobi i interesa. 


\section{LITERATURA}

Antić, N. Kretanje stanovništva Grada Zagreba s posebnim osvrtom na doseljavanje u razdoblju 1991. - 2001. // Migracijske i etničke teme 17, 287-309.

Babić, I.; M. Bily; I. Klak Mršić. Sesvetski pjesnički maraton: Istraživanje zadovoljstva korisnika. // Vjesnik bibliotekara Hrvatske 62, 2(2019), 227-246. [citirano: 202110-05]. Dostupno na:

https://www.hkdrustvo.hr/vjesnik-bibliotekara-hrvatske/index.php/vbh/article/ view/776.

Cej, V.; K. Krpan; I. Klak Mršić. Primjena razvojne biblioterapije u radu s djecom i mladima u narodnoj knjižnici. // Vjesnik bibliotekara Hrvatske 61, 1(2018), 345-361. [citirano: 2021-10-05]. Dostupno na:

https://www.hkdrustvo.hr/vjesnik-bibliotekara-hrvatske/index.php/vbh/article/ view/621/574.

Državni zavod za statistiku. Popis stanovništva, kućanstava i stanova 2011. [citirano: 2021-10-05]. Dostupno na: https://www.dzs.hr.

Gomerčić, N. Narodne knjižnice u Hrvatskoj jučer, danas i sutra. // Vjesnik bibliotekara Hrvatske 40, 12(1997), 79-89.

Grad Zagreb: Gradska četvrt Sesvete. [citirano: 2021-10-05]. Dostupno na: https://aktivnosti.zagreb.hr/gradske-cetvrti-19/sesvete/163.

Grgić, S. Narodne knjižnice grada Zagreba. // Vjesnik bibliotekara Hrvatske 8, 12(1962), 35-47.

Horjan, I. Javno priznanje knjižnici Sesvete. // Sesvetske novine 56(1975), 6.

IFLA-ine smjernice za narodne knjižnice: 2. hrv. izd. (prema drugome izmijenjenom izd. izvornika). / uredile C. Koontz i B. Gubbin. Zagreb: Hrvatsko knjižničarsko društvo, 2011.

Knjižnice grada Zagreba. Galerija Oblok. [citirano: 2021-04-08]. Dostupno na: http://www.kgz.hr/hr/knjiznice/knjiznica-sesvete/galerija-oblok/o-galeriji-53775/53775.

Knjižnice grada Zagreba. Knjižnica Dubec. [citirano: 2021-04-08]. Dostupno na: http://www.kgz.hr/hr/knjiznice/knjiznica-dubec/69.

Knjižnice grada Zagreba. Knjižnica Jelkovec. [citirano: 2021-04-08] Dostupno na: http://www.kgz.hr/hr/knjiznice/knjiznica-jelkovec/7116.

Knjižnice grada Zagreba. Knjižnica Selčina. [citirano: 2021-04-08]. Dostupno na: http://www.kgz.hr/hr/knjiznice/knjiznica-selcina/84.

Knjižnice grada Zagreba. Knjižnica Sesvete. [citirano: 2021-04-08]. Dostupno na: http://www.kgz.hr/hr/knjiznice/knjiznica-sesvete/85. 
Knjižnice grada Zagreba. Kulturni četvrtak u Sesvetama. [citirano: 2121-07-08] Dostupno na: http://www.kgz.hr/hr/knjiznice/knjiznica-sesvete/kulturni-cetvrtak-u-sesvetama/7724.

Klak Mršić, I. Otvorena Knjižnica Jelkovec u mreži Knjižnica grada Zagreba. // Novosti Hrvatskog knjižničarskog društva 58(2013). [citirano: 2021-04-02]. Dostupno na: https://www.hkdrustvo.hr/hkdnovosti/clanak/630.

Malić, A. Transformacija Sesveta pod utjecajem Zagreba. // Hrvatski geografski glasnik 31, 1(1969), 143-153. [citirano: 2021-05-10]. Dostupno na: https://hrcak.srce. $\mathrm{hr} / 56058$.

Mjesni odbor Novi Jelkovec. [citirano: 2021-10-03]. Dostupno na: https://www.zagreb. hr/27-mjesni-odbor-novi-jelkovec/15469.

Opremanje i izgradnja knjižnice: Planiranje i izgradnja Knjižnice Jelkovec.[citirano: 2021-11-03]. Dostupno na:

http:/www.kgz.hr/hr/knjiznice/knjiznica-jelkovec/o-knjiznici-7117/opremanje-i-izgradnja-knjiznice/28586.

Prlić, D. Nova knjižnica u naselju Novi Jelkovec u Sesvetama. // Novosti Hrvatskog knjižničarskog društva 48(2012) [citirano: 2021-03-02]. Dostupno na: https://www.hkdrustvo.hr/hkdnovosti/clanak/271.

Standardi za narodne knjižnice u Republici Hrvatskoj. // Narodne novine 58, 1071(1999). [citirano: 2021-30-03]. Dostupno na: https://narodne-novine.nn.hr/clanci/sluzbeni/1999_06_58_1071.html.

Stipanov, J. Povijest knjižnica i knjižničarstva u Hrvatskoj. Zagreb: Školska knjiga, 2015.

Šišak, I. Utjecaj doseljavanja na funkcionalno-prostornu transformaciju Gradske četvrti Sesvete: Diplomski rad. Zagreb: Sveučilište u Zagrebu, Prirodoslovno-matematički fakultet, 2018. [citirano: 2021-01-06]. Dostupno na:

https://repozitorij.pmf.unizg.hr/islandora/object/pmf:4770.

Upute za poslovanje narodnih knjižnica. / uredila A. Malnar. Zagreb : Knjižnice grada Zagreba, 1996.

Zakon o bibliotekama. // Vjesnik bibliotekara Hrvatske 6, 3/4 (1960), 75-81.

\section{Arhivsko gradivo}

Arhiva Knjižnice Sesvete. Arhitektonsko građevinski projekt.

Arhiva Knjižnice Sesvete. Izvještaj o radu Knjižnice Dubec za 2007. godinu.

Arhiva Knjižnice Sesvete. Izvještaj o radu Narodne knjižnice Sesvete za 1964. godinu.

Arhiva Knjižnice Sesvete. Izvještaj o radu Narodne knjižnice Sesvete za 1967. godinu.

Arhiva Knjižnice Sesvete. Izvještaj o radu Narodne knjižnice Sesvete za 1968. godinu.

Arhiva Knjižnice Sesvete. Izvještaj o radu Narodne knjižnice Sesvete za 1970. godinu. 
Arhiva Knjižnice Sesvete. Izvještaj o radu za 1988. godinu.

Arhiva Knjižnice Sesvete. Izvještaj o radu za 1989. godinu.

Arhiva Knjižnice Sesvete. Knjižna stanica Dubec.

Arhiva Knjižnice Sesvete. Knjižnica Sesvete uspješna adaptacija nenamjenskog prostora.

Arhiva Knjižnice Sesvete. Knjižnice grada Zagreba: Izvještaj stručnih suradnika Matične službe za planiranje i izgradnju bibliotečnih prostora.

Arhiva Knjižnice Sesvete. Narodno sveučilište Sesvete: Izvještaj o radu za 1975. godinu.

Arhiva Knjižnice Sesvete. Narodno sveučilište Sesvete: Izvještaj o radu za 1978. godinu

Arhiva Knjižnice Sesvete. Odluka Radne zajednice Narodne knjižnice Sesvete.

Arhiva Knjižnice Sesvete. Osnovna radna organizacija za projektiranje i srodne tehničke usluge: Nadogradnja doma kulture Sesvete.

Arhiva Knjižnice Sesvete. Pregled ostvarenja programa rada zagrebačkih narodnih knjižnica u 2000. godini.

Arhiva Knjižnice Sesvete. Pregled poslovanja Knjižnice Dubec od 1974. do 1982. godine.

Arhiva Knjižnice Sesvete. Prijedlog plana rada Narodne knjižnice Sesvete 1970.-1975. godine.

Arhiva Knjižnice Sesvete. Prijedlog za integraciju Narodnog sveučilišta i Narodne knjižnice Sesvete.

Arhiva Knjižnice Sesvete. Problem prostora Knjižnice Dubec.

Arhiva Knjižnice Sesvete. Program rada za 1987. godinu.

Arhiva Knjižnice Sesvete. Promemorija Knjižnice Dubec.

Arhiva Knjižnice Sesvete. Rješenje upisa u registar ustanova.

Arhiva Knjižnice Sesvete. Stanje narodnih knjižnica na području Sesveta.

Arhiva Knjižnice Sesvete. Zapisnik sa sjednice savjeta Narodne knjižnice i čitaonice Sesvete. 29.12.1960.

Arhiva Knjižnice Sesvete. Zapisnik sjednice upravnog odbora Narodne čitaonice i knjižnice u Sesvetama 1957.-1963.

Arhiva Knjižnice Sesvete. Žerjavić radna organizacija za projektiranje: Uređenje Knjižnice Selčina. 